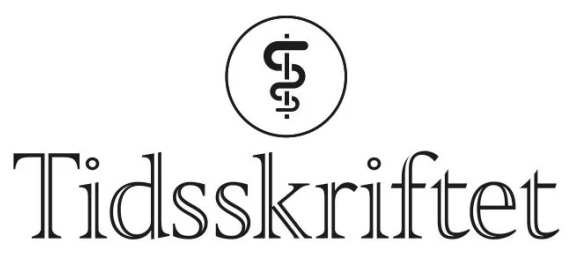

DEN NORSKE LEGEFORENING

\title{
Redaksjonen svarer:
}

\author{
SPRÅKSPALTEN
}

ERLEND HEM

Erlend Hem (f. 1970) er assisterende sjefredaktør i Tidsskriftet.

Email: erlend.hem@medisin.uio.no

I boken Hva er godt riksmål? skrev André Bjerke (1918-85) at høres ut er en av de mest utbredte «sprogpadder» (1). Han medga riktignok at uttrykksmåten var «hårdnakket» levedyktig, men den kvalifiserer ikke «til noen oppholdstillatelse i vårt kultursprog», mente han (11). Opprinnelig var høres ut en sammenblanding av høres og ser ut. «Dette "ut» har mening når det dreier seg om synsuttrykk: blikket oppfatter tingenes fasade, det som vender ut mot øyet», men det blir meningsløst, overført på hørselen, ifølge Bjerke (므).

Alt da Bjerke skrev dette i 1960-årene, var det en tapt kamp. På Riksmålsforbundets hjemmesider står det nå at høres ut «ikke lenger regnes som feil, og det har forankring $\mathrm{i}$ skriftspråktradisjonen. Blant annet finner vi det både hos Hamsun og Nils Kjær. I moderne riksmål er det valgfritt om man ønsker å skrive høres eller høres ut» (3).

Høres ut er altså opphavlig en sammenblanding av to begreper. Språkviterne kaller det for en kontaminasjon (4). Høres ut har ennå sine motstandere, men er nå så vanlig i skrift og tale at det er fåfengt å prøve å motarbeide det $(5,-6)$. I ordbøker er høresut faktisk oppført som eneform (7.), og et nettsøk gir langt flere treff på «høres ut som» enn «høres som» - også i Tidsskriftets nettutgave. Man trenger altså ikke kjenne det minste stikk i sin språklige samvittighet om man sier og skriver høres ut.

I visse tilfeller kan det være en betydningsforskjell mellom høres og høres ut. «Stykket høres godt» (= det er lett å høre det) versus "Stykket høres godt ut» (= det virker som det er godt) (5). Se hvordan Johan Falkberget (1879-1967) får frem denne nyansen: «doktoren sa at hjertet hennes hørtes riktig elendig ut» ( $\underline{8})$.

Også «føles ut» og «kjennes ut» forekommer, men uttrykkene blir ikke regnet for korrekte, ifølge Finn-Erik Vinje, som også frarår en formulering som denne: «Eksperimentet forløp heldig ut» (av «forløp heldig» og «løp heldig ut»)(5).

\section{LITTERATUR}

1. Bjerke A. Hva er godt riksmål? Spørsmål og svar. 2. utg. Oslo: Riksmålsforbundet, 1967:30-2. www.nb.no/nbsok/nb/3ce6oo6e6d3739dbcd441256aa8c3e1e?index=1\#31 (31.3.2014).

2. Bjerke A. Dannet talesprog. Oslo: Riksmålsforbundet, 1966: 47. www.nb.no/nbsok/nb/569de6371059e6fdodb6fbo364738f2o?index=2\#48 (31.3.2014). 
3. Høres (ut)? Riksmålsforbundet. www.riksmalsforbundet.no/Språktjenester/Språkspalten/Diverse.aspx? $\mathrm{PID}=329 \& \mathrm{M}=\mathrm{NewsV} 2 \&$ Action $=1 \& \mathrm{NewsId}=74$ (31.3.2014).

4. Hem E. Smittsom speiling. Tidsskr Nor Legeforen 2010;130: 1502.

5. Vinje F-E. Moderne norsk: en veiledning i skriftlig framstilling: morfologiske og syntaktiske vanskeligheter. 5. utg. Bergen: Fagbokforlaget, 2002: 456.

6. Diskusjonsforum ved UiO: Høres (ut?) som. 29.11.2009. https://diskusjonsforum.uio.no/thread.jspa?threadID=9o (31.3.2014).

7. Høres. I: Bokmålsordboka. www.nob-ordbok.uio.no/perl/ordbok.cgi? $\mathrm{OPP}=\mathrm{h} \% \mathrm{C}_{3}$ \%B8res\&bokmaal=+\&ordbok=bokmaal (31.3.2014).

8. Falkberget J. Fimbulvinter. I: Runer på fjellveggen: sagn og fortellinger. Oslo: Aschehoug, 1944: 249. www.nb.no/nbsok/nb/776fee23965ede5d5e373c36b2e6e356?index=1\#252 (31.3.2014).

9. Ibsen H. Bygmester Solness (1892). I: Samlede værker. Bd. 9. København: Gyldendalske Boghandels Forlag (F. Hegel \& søn), 1900: 103. http://runeberg.org/ibsen/9/o131.html (30.3.2014).

Publisert: 27. mai 2014. Tidsskr Nor Legeforen. DOI:10.4045/tidsskr.14.0582

Mottatt 31.3. 2014 og godkjent 7.4. 2014. Redaktør: Marit Fjellhaug Nylund.

(C) Tidsskrift for Den norske legeforening 2023. Lastet ned fra tidsskriftet.no 26. april 2023. 